\title{
The Development of Learning Media for Batik Stamp Tools Made from Used Paper for Primary Education
}

\author{
Febritesna Nuraini \\ Department of Early Childhood Education Teacher Training \\ Universitas Ahmad Dahlan \\ Yogyakarta, Indonesia \\ febritesna.nuraini@pgpaud.ac.id
}

\author{
Probosiwi, Fery Setyaningrum \\ Department of Primary Education Teacher Training \\ Universitas Ahmad Dahlan \\ Yogyakarta, Indonesia
}

\author{
Santo Mugi Prayitno \\ Sekolah Dasar Bangunrejo 2 \\ Yogyakarta, Indonesia
}

\begin{abstract}
This research aims to develop learning media in the form of batik tools, for prospective teachers of primary education and early childhood education, and test the effectiveness of the tools developed. Media has an essential role in the learning process because the media is a tool in understanding knowledge. Batik is local content-based learning. The study is following the steps in research and development research design. The subjects in this study were the students of teacher education. Based on the results, it can be concluded that the media is feasible for practice and may be effective to increase student activity.
\end{abstract}

\section{Keywords-media cap tool-based recycling; basic education}

\section{INTRODUCTION}

The 2013 curriculum emphasizes the development of regional potential that is packaged in learning local content [1]. Local content learning is a program taught from high school up to early childhood education. Local content studies three kinds, namely the natural environment, social environment, and cultural environment [2]. Where each local content has a type, the nature of the study material is different. There are three objectives for learning local content [3], that are students are familiar with their environment, both from the natural environment, social environment and cultural environment, students gain skills for life, and students realize environmental conditions. Referring to these objectives, local content is illustrated to be able to equip students and students to recognize, understand and be skilled as a provision of future life, so that they can develop in various conditions of the era without forgetting the culture and environment in which they live.

One of the local contents developed at school is Batik because Batik is one of the potential local products of cultural products. Batik is a high-value craft. Batik is one of Indonesia's high-value heritages [4], which is hand-scraped. Batik is a craft that has high artistic value and has become part of Javanese culture. Batik is closely related to Javanese culture and the values that exist in society so that Batik is not a product of mere production but is a result. Batik is not only a product of production but also a cultural product of society [5]. Batik making techniques are divided into three types according to their characteristics [6]; Batik writing (tulis), Batik stamp (cap), and Batik painting (lukis). The techniques for making Batik in Thailand are of two types of chanting and stamp techniques [7]. Batik techniques are not only found in Indonesia but also in several other countries [8].

As known, many people began to develop Batik with modern tools and began to leave the making of Batik traditionally. This can be seen from several research results [9], developing batik tools using digital media in learning batik appreciation. Also, the results of research conducted by Sianipar, Kusuma, and Ansori [10] used the development of the Random Walk method. The Random Walk method is a method for making jellyfish batik designs using a random walk. The tools used in the previous two studies are quite complicated and require people who are experts in their field. Research conducted [10] redesigned canting using electricity because it saw a phenomenon in the field when using an old chanting looked dirty.

The results of observations of social content learning in several educational institutions, when learning Batik, some schools do not introduce copper-based batik stamp, in addition to massive and expensive. Schools are more likely to teach Batik in modern and straightforward ways, such as weaving, binding, and dipping techniques. Observation results in kindergarten learning batik introduced by tasting using a banana midrib. For batik techniques using copper stamp batik tools, not all schools introduce, only vocational schools majoring in Arts.

Based on the results of research and observation in the field so that the preservation of Batik is maintained and batik learning activities as local content can run well develop children's creativity and interests. So Batik is needed tools that can stimulate children's creativity. The stamp tool that was developed was made from used materials, such as; used wood and duplex paper or more familiar with paper for snack places. Where used snack boxes are usually only thrown away, and 
[11] is a Wayang (Javanese puppet show) learning media based on duplex paper.

The duplex paper used in the development of learning media, because this paper has good quality, and is recycled paper. Rahmani et al [12] stated that duplex paper has good quality because, during the manufacturing process, there are chemical compounds. Research results [13] this paper presents an assessment framework connecting customer value dimensions with simulations conducted on the mechanical properties of the packaging material and discusses how value modeling results can be visualized to support collaborative decision making in cross-functional teams.

\section{METHOD}

This research is research and development (R\&D), which follows the development model that belongs to Gall, Gall, and Borg [14]. Development research is a development model, where research findings are used to design new procedures and products, where the new procedures and products are then systematically tested in the field, evaluated, and refined until they reach the criteria of effectiveness and quality according to established standards. The resulting product is a tool for Batik.

This study refers to Gall, Gall, and Borg [14], which consists of 10 steps, but in this study, it was modified into 4 stages. The four stages of development are initial investigation, design, testing, evaluation, and revision, and implementation. Determination of research subjects also follows the steps of Brog and Gall, namely the number of subjects that continues to increase in number from the first, second, and third trials. The subjects in this study amounted to the end of 150 students. Described: first try out: 30 students, second try out 50 students and third try out: 70 students.

\section{RESULTS AND DISCUSSION}

The research was conducted to 150 students of the Primary Education Teacher Training (PGSD), and the Early Childhood Teacher Education (PGPAUD). The data was collected using questionnaire, interview, and observation. Requirement analysis, which is the basis in developing learning media in the form of a batik stamp tool from recycled materials is to help facilitate students and students in developing an interest in producing work.

The developed batik stamp was made of wood waste, scrap paper from cardboard, where this piece of wood or wastepaper ends up being rubbish or piles in a warehouse. By this waste researcher, it was made a useful tool, bearing in mind that the batik stamp tool that had been used was made of copper which was quite heavy when used by elementary school children and early childhood education. Following is a drawing of a batik tool Figure.1. A. The Old Model Batik Stamp Tool and Figure 1. B. is the Batik tool developed.
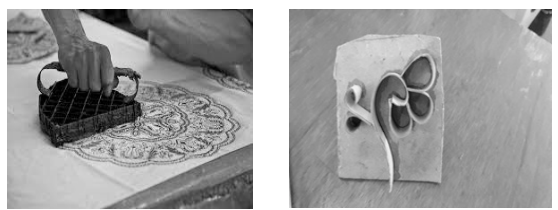

Fig. 1. A. old model Batik cap tool, B. the Batik tool developed

The batik stamp was developed in the form of a series of paper, wooden boards drawn and pasted with "duplex paper." This Batik stamping batik media tool was developed through several stages, the first of which was drawing designs on paper, while drawing can combine various patterns that suit them, such as floral patterns, leaves or batik patterns from outside Java, and simple patterns adapted to individual ability level. The second stage, the pattern that has been drawn on the paper is transferred to a wooden board. The third stage then uses paper; the pattern is formed, like the Figure 1.B.

Before being used in real learning, all devices are vided from experts and practitioners. Components that are validated by experts (experts and practitioners) consist of (1) components and procedures for the use of printed paper batik made of used goods, (2) instruments and their lattices, (3) tools and materials. This validation test is carried out by FGD (Focus Group Discussion). Based on the expert validation process obtained as follows According to experts and practitioners, the use of batik stamp tools by utilizing used materials is constructive in the learning process, especially in learning the local content of making Batik. Also, children will be motivated to apply Batik with new techniques or methods.

Moreover, children will be increasingly rich in knowledge about Batik. Utilization of used materials will have an economic impact. For children, it is also not too heavy, considering the batik stamp tool or often called the chanting stamp Made of copper and expensive. The results of expert validation assessed by experts and practitioners show good enough worthiness. After validating the expert's test, the first or limited trial was conducted using 30 students, divided into five groups. Based on preliminary analysis, there is input from experts and experts when practice takes place, stating students are given debriefing in drawing patterns following the characteristics of students, both for elementary school children and early childhood education. After that, it can be tested into the second group. Students are still finding it difficult to find used wood that is used as a base, and they prefer to buy goods that are ready or cut. Besides, when mixing colors for essential ingredients, they tend to buy ready-made materials, not based on the instructions that have been delivered.

The second trial, the second trial data uses. Fifty respondents divided into ten groups. Referring to this secondary analysis carried out with the same tools as the improvement students were given debriefing to draw natural patterns and got input from peers when measuring and cutting paper more attention so that the results were straight and not tingling. Besides, there were also students found when drawing paper patterns still seeing examples from lecturers.

The third trial uses 70 students divided into 14 groups, showing that the improvement is quite good, this can be seen 
from the activeness and development of creations also increasing, although there is still something to be helped in the technique of pattern arrangement and color mixing.

According to the Expert and practitioners, the batik stamp media based on recycling is beneficial in the learning process, especially local content batik. Teachers can be creative and create works without leaving the specific culture, especially Javanese culture, namely batik. Besides that, it helps children to be more motivated to develop an action. This batik stamp from recycled material is also able to increase children's activeness because they finally find ideas, explore an example of work, and assemble ideas with prior experience until the child can discover appropriate patterns. The use of a batik stamp made from used materials can be a visual communication medium that has the power to convey information quickly, notably introducing a variety of Batik. This is possible considering that the batik stamp tool is arranged in one master consisting of one pattern, and the teacher and child can apply on batik cloth [16-17]. [3] However, in these contexts, direct may be provided on a justin-time basis and generally, once students experience the need to know the information presented.

According to Hamalik [18] states that learning with interest will encourage children to have a good impact on those who do not. This is in line with the results of research conducted [19] showing children who have an interest in learning and the media that are supporting have a positive impact because the media can convey a message that is captured in the child. Like the batik stamp tool as a learning medium that serves to convey the message. In this context, learning refers to a communication process in introducing various batik patterns.

\section{CONCLUSION}

The conclusion in this study are as follows, first, the media in the form of primary material made from used materials is carried out in four stages, namely: the initial investigation stage, the design stage, the trial phase, the evaluation and revision, and the implementation phase. So, that it can produce media in the form of a batik stamp based on recycling. Furthermore, the basic cap can foster a positive attitude towards students. It can be seen from their efforts to look for examples of pattern images and look for necessary materials for tools.

\section{REFERENCES}

[1] I. Hanafi, I. Zakir, D. Daryanto, T. Taryudi, and R. Febriana, "Development of vocationalization model of basic education based on local wisdom in era of asean economic community," in Proceedings of the 5th UPI International Conference on Technical and Vocational Education and Training (ICTVET 2018), 2019.

[2] S. Arikunto, Pengembangan program muatan lokal. Yogyakarta: UNY, 2006.

[3] A. J. Pesurnay, "Local wisdom in a new paradigm: applying system theory to the study of local culture in Indonesia," IOP Conf. Ser. Earth Environ. Sci., vol. 175, no. 1, 2018.

[4] A. Yudoyono, Batikku pengabdian cinta tak berkata. Jakarta: Gramedia Pustaka Utama, 2010.

[5] H. Lisbijanto, Batik. Yogyakarta: Graha Ilmu, 2013.
[6] Hamzuri, Batik klasik. Yogyakarta, 1983

[7] K. K. 2, A. P. D. N. L. 3, and A. P. D. J. Vongphantuset, "Modular batik stamp block Development of southern Thai Printing batik stamp block," Humanit. Soc. Sci. arts, vol. 8, no. 4, pp. 127-142, 2015.

[8] N. Libriani, "Pengembangan alat untuk pewarnaan batik wet on wet," Fash. Fash. Educ. J., vol. 3, no. 1, pp. 6-9, 2014.

[9] S. S. Rupa, F. Bahasa, and U. Alamat, "Penerapan media digital dalam pembelajaran apresiasi batik kelas x SMA negeri 1 Blega," J. Pendidik. Seni Rupa, vol. 01, pp. 100-105, 2013.

[10] T. D. A. Sianipar, P. D. Kusuma, and A. S. R. Ansori, "Pengembangan motif ubur-ubur jenis chrysaora colorata pada aplikasi batik berbasis web dengan metode random walk," eProceedings Eng., vol. 6, no. 1, Apr. 2019

[11] P. Putriningtyas and S. Setyowati, "Pengaruh penggunaan media wayang dupleks komunikasi terhadap kemampuan berbicara anak kelompok B," PAUD Teratai, vol. 4, no. 2, 2015.

[12] I. Dwi Rachmani, F. Kusnandar, N. Dewi Yuliana, Y. Regina, M. Y. Massijaya, and S. Budijanto, "3-monochoro-1,2-propandiol in duplex paper packaging and its migration into food simulant," J. Teknol. dan Ind. Pangan, vol. 26, no. 1, pp. 44-51, 2015.

[13] M. Bertoni, S. A. Chowdhery, and A. Bellini, "Model-driven value assessment: a case from the food packaging industry," 2018, pp. 161170.

[14] W. R. Gall, M.D., Gall, J.P., \& Brog, Educational research: An introduction., $8^{\wedge}$ thed. New York: Pearson Education, Inc., 2007.

[15] I Wayan Gunarta, Pengembangan model evaluasi program layanan paud. Yogyakarta: Universitas Negeri Yogyakarta, 2014.

[16] H. G. Schmidt, "Problem-based learning: rationale and description," Med. Educ., vol. 17, pp. 11-16, 1983.

[17] J. D. Schwartz, D. L., \& Bransford, "Time for telling," Cogn. Andin., vol. 16, pp. 475-522, 1998.

[18] Hamalik, Perencanaan pengajaran berdasarkan pendekatan sistem. Jakarta: Bumi Aksara, 2003

[19] Ary Nur Wahyuningsih, "Pengembangan media komik bergambar materi sistem saraf untuk pembelajaran yang menggunakan strategi PQ4R," Juornal Innov. Sci. Educ., vol. 1, pp. 20-27, 2012. 